\title{
Availability and estimation of crop by-product yields for small ruminant production in Cross River State, Nigeria
}

G.A. Kalio, L.N. Agwunobi*, A.A. Ayuk and C. A. Eneji

Department of Animal Science, University of Calabar, Calabar

e-mail address: link_leonard@yahoo.com

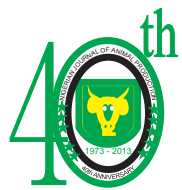

\begin{abstract}
A study was carried out in some Local Government Areas of Cross River State of Nigeria to identify and ascertain the availability, level of production and the yields of crop by-products derived from commonly cultivated crops that can serve as feed for small ruminants. The results show that the various staple crops commonly grown in Cross River State produce the following crop by-products in a decreasing order of yields-cassava peels $>$ yam peels $>$ corn cobs $>$ maize sheaths $>$ plantain peels $>$ maize offal $>$ rice offal $>$ cassava sievets $>$ banana peels $>$ fried garri sievets $>$ groundnut haulms $>$ sweet potato peels. The annual yield of crop by-products per Local Government Area is estimated as follows: cassava peels 89,226.40, yam peels 32,318.80, maize sheaths and offal 358,050.00, rice 0ffal 37,140.00, cowpea haulms 34,064.00, groundnut haulms 41,872.00, banana peels and rejects 18,420.00, plantain peels 7,598.40, cocoyam peels 11,944.00, sweet potato peels and rejects 8,024.00 tonnes per selected LGA.The total amount of crop by-products $(638,657.60$ tonnes) generated each year from the staple food crops will go a long way in solving the problem of feed scarcity for ruminants during dry season.
\end{abstract}

Key words: crop by-products, dry seas on feeding, small ruminants.

\section{Introduction}

One of the most difficult problems in ruminant production in the tropics is the dry season feeding of ruminant animals. During this period, there is, generally, scarcity of green fodder. The roughages are usually dry, deficient in protein and energy content. There is a marked decrease in voluntary intake and digestibility. Consequently, the animals lose substantial weight. This has been the situation in Cross River State every year. In some more advanced countries like Brazil, with a similar tropical condition, this problem of scarcity is well managed by harnessing the agro byproducts to feed ruminants at lean period (Devendra, 1989, Devendra and Seville, 2002, Williams et al 1997, Henning et al ;
2006).

In Nigeria, millions of tonnes of crop byproducts are generated every year in our rural communities as unavoidable crop byproducts or residues. These constitute waste and a nuisance to the environment if they are not properly disposed. However, their use in feeding ruminants will not only solve the problem of environmental pollution but also will provide the population with the much needed meat and milk.

There is limited information on the availability, quantity, quality and utilization of the locally produced wide range of crop by-products by small-holder goat farmers in Cross River State. Furthermore, the demand for conventional sources of proteins has exceeded supply. Consequently, wastes generated from 
harvesting and processing of staple food crops may serve as useful alternatives to conventional protein feed sources. The objective of this paper, therefore, is to estimate the quantity of crop by-products produced in Cross River State which could be harnessed for dry season feeding of ruminants.

\section{Materials and Methods}

The information on the values of crop yields and farm animal population were obtained from farmers by means of questionnaire administered randomly to selected farmers representing the selected Local Government Areas of Cross River State in the three senatorial districts. Two (2) Local Government Areas each were selected from these senatorial districts and four (4) villages each making a total of twenty-four (24) villages were randomly selected for the study.

The study was carried out through the use of structured questionnaires. A total of three hundred and sixty (360) questionnaires were used for the study and they were randomly distributed to household of fifteen (15) per village. The questionnaires were distributed to the farmers while they were on the field or at home. A hundred percent recovery rate of the questionnaires was achieved owing to the aggressive follow up of the respondence. Relevant information was collected through these questionnaires and where difficulties were encountered by the respondents, direct interviews were adopted. Completed questionnaires were retrieved and analyzed through descriptive statistics using simple percentages and the results were presented in tables.

The yield of crop by-products was estimated from the target crops using multipliers formulated by El-Wouby 1991 and Rosillo-Calle, et al. (2008). The authors established the following values as residue production coefficient (or multipliers) on air dry basis for some crops. The values are $4,1.3$ to $3,1.0,0.55,0.4$ and 0.3 for beans, cereals, vegetables and melons, sugar cane, root and tubers and sugar beet respectively.

\section{Results and Discussions}

The summary of the food crops and associated finished products produced within the selected Local Government of Cross River State is shown in Table 1. The crops cultivated through mono and mixed cropping systems in the order of decreasing percentages include yam $>$ maize $>$ cassava $>$ plantain $>$ cocoyam $>$ banana $>$ groundnut $>$ rice $>$ benniseed $>$ sweet potato $>$ cowpea $>$ sorghum $>$ millet. These crops represent the list of some staple food crops cultivated in the South-South Region of Nigeria. Majority of these crops (80.06\%) were cultivated within the months of February and April, while others : $13.10 \%, 4.76 \%$ and $2.08 \%$ were within the months of MayJuly, August-October and NovemberDecember respectively.

The food crops harvested in the order of decreasing percentages were as follows: Cassava tuber $>$ maize $>$ yam tuber $>$ plantain $>$ cocoyam $>$ banana $>$ sweet potato $>$ rice. The finished products derived from these crops were garri $>$ fufu $>$ corn meal $>$ tapioca $>$ agidi $>$ cassava flour $>$ cassava chips $>$ groundnut cake $>$ local brewed beer (brukutu) > groundnut oil.

Table 2 shows the total yield of the various crops in the selected Local Government Areas of Cross River State as well as the total quantity of land required to produce each of these crops.

It revealed that cassava recorded the highest yield (4460.70 tonnes) with a total land equivalence of 109.012 hectares, while cocoa recorded the least yield (61.5 tonnes) with a total land equivalence of 3.003 
Table1: Food crops and associated finish ed product produced in the selected LGA (Local Govern ment Area) of Cross River State

\begin{tabular}{|c|c|c|c|}
\hline Criterion & Response & No. of respondents & Percentage \\
\hline Cropping system & Mono cropping & 60 & 32.6 \\
\hline \multirow[t]{2}{*}{ adopted } & Mixed cropping & 124 & 67.4 \\
\hline & Total & 184 & 100 \\
\hline \multirow[t]{14}{*}{ Crops cultivated } & Yam & 129 & 21.11 \\
\hline & Maize & 110 & 18.00 \\
\hline & sweet potato & 19 & 3.11 \\
\hline & Cocoyam & 45 & 7.36 \\
\hline & Rice & 29 & 4.75 \\
\hline & Groundnut & 42 & 6.87 \\
\hline & Cas sava & 94 & 15.38 \\
\hline & Cowpea & 12 & 1.96 \\
\hline & Benniseed & 21 & 3.44 \\
\hline & Millet & 0 & 0.00 \\
\hline & Sorghum & 5 & 0.82 \\
\hline & Plantain & 61 & 9.98 \\
\hline & Banana & 44 & 7.20 \\
\hline & Total & 611 & 100.00 \\
\hline \multicolumn{4}{|l|}{ Months of the year } \\
\hline & May- July & 44 & 13.10 \\
\hline & August - October & 16 & 4.76 \\
\hline & Nov. - Dec. & 7 & 2.08 \\
\hline & Total & 336 & 100 \\
\hline
\end{tabular}

hectares.

Table 3 shows the estimated values of crop residues obtained from the yield of each crop using crop residue coefficients or multipliers (Kossila 1986, EL-Nouby
1991, Rosillo-Calle et al., 2008). The rankings revealed that higher crop residues or by-products were generated from the first four crops: maize, cassava, groundnut and rice. The order of ranking in decreasing

Table 2: Estimated total crop yields and associated land equivalence in the Local Government Areas investigated in Cross River State

\begin{tabular}{llllllllllllll}
\hline \hline Parameters & CSV & YM & MZ & RE & COWP & GRDN & BA & PLT & CCY & BNS & COC & SWP & Total \\
\hline $\begin{array}{l}\text { Total yield } \\
\text { (tonnes) }\end{array}$ & 4460.7 & 807.9 & 1193.5 & 247.6 & 85.2 & 104.7 & 460.5 & 189.9 & 298.6 & 79.8 & 61.5 & 200.6 & 8190.5 \\
$\begin{array}{l}\text { Total land } \\
\text { (hectare) }\end{array}$ & 109.0 & 39.5 & 58.3 & 12.1 & 4.2 & 5.1 & 22.5 & 9.3 & 14.6 & 3.9 & 3.0 & 9.8 & 291.3 \\
$\begin{array}{l}\text { Average } \\
\text { land per }\end{array}$ & 18.2 & 6.6 & 9.7 & 2.0 & 0.7 & 0.9 & 3.8 & 1.6 & 2.4 & 0.6 & 0.5 & 1.6 & \\
$\begin{array}{l}\text { LGA } \\
\text { (hec.) }\end{array}$ & & & & & & & & & & & & & \\
\end{tabular}

$\mathrm{CSV}=$ cassava; $\mathrm{YM}=$ yam; $\mathrm{MZ}=$ =maize; RE=rice; $\mathrm{COWP}=$ cowpea; GRDN=groundnut; $\mathrm{BA}=$ banana; $\mathrm{PLT}=$ plantain; $\mathrm{CCY}=$ cocoyam; $\mathrm{BNS}=$ benniseed; $\mathrm{COC}=$ cocoa; $\mathrm{SWP}=$ sweet potato. 
yield was maize $>$ cassava $>$ groundnut $>$ rice $>$ cowpea $>$ yam $>$ banana $>$ cocoyam $>$ sweet potato $>$ plantain.

The crop by-products used in livestock feeding in order of decreasing importance as responded by livestock farmers include cassava peels $>$ yam peels $>$ corn cobs $>$ maize sheath $>$ plantain peels $>$ maize offal $>$ rice offal $>$ cassava sievets $>$ banana peels $>$ fried gari sievets $>$ groundnut haulms $>$ sweet potato peels.

These material have been reported as readily available and cheap sources of feedstuffs for both ruminants and nonruminants in Nigeria (Oyenuga, 1978; Tewe and Kasali, 1986; Farrell et al., 2000; Idowu et al.,2005; Olurunmisomo et.al., 2005; Dawang, 2006) and Ghana (Tuah et al., 1994).

The higher quantity of crop residues and by-products recorded by cassava and maize from the study may be attributed to higher rate of production of the two crops, and the variety of residues or by-products generated from either of the crops- peels, sievets from cassava tubers and cobs, offal, and sheath from maize.

The quantity of crop by-products produced annually in Cross River State is so large that if it is not utilized for animal feed or farm yard manure may constitute environmental hazard in the State.

Table 4 shows the estimates of farm animal population in a single and mixed herd owned by farmers in different households in the study area. The information from this table showed that the 80 farmers who kept their farm animals in single population keep average of 3.04 (approximately 3 ) goats, 1.59 (approximately 2) sheep, 2.11 (approximately 2) fowls with little or no numbers of duck, pig and cattle by approximation.

Table 3: Yields of crop by-p roducts estimated from crop yields

\begin{tabular}{lllll}
\hline Crop & $\begin{array}{l}\text { Total crop yield } \\
\text { (tonnes) }\end{array}$ & $\begin{array}{l}\text { Crop residues } \\
\text { production } \\
\text { coefficient } \\
\text { multipliers }\end{array}$ & $\begin{array}{l}\text { Potential } \\
\text { residue and by- } \\
\text { product } \\
\text { (tonnes) }\end{array}$ & $\begin{array}{l}\text { crop } \\
\text { yield }\end{array}$ \\
\hline Cassava & 4460.7 & $0.4^{*}$ & 1784.3 & 2 \\
Yam & 807.9 & $0.4^{*}$ & 323.2 & 6 \\
Maize & 1193.5 & $3.0^{* *}$ & 3580.5 & 1 \\
Rice & 247.6 & $1.5^{* *}$ & 371.4 & 4 \\
Cowpea & 85.2 & $4.0^{*}$ & 340.8 & 5 \\
Groundnut & 104.7 & $4.0^{*}$ & 418.8 & 3 \\
Banana & 460.5 & $0.4^{*}$ & 184.2 & 7 \\
Plantain & 189.9 & $0.4^{*}$ & 75.9 & 10 \\
Cocoyam & 298.6 & $0.4^{*}$ & 119.4 & 8 \\
Benniseed & 79.8 & nil & Nil & nil \\
Cocoa & 61.5 & nil & Nil & nil \\
Sweet potato & 200.6 & $0.4^{*}$ & 80.2 & 9 \\
\hline Total & 8190.5 & & 7278 & \\
\hline \hline
\end{tabular}

Assumptions: *crop residue coefficients or multiplier (tuber and root crops) adopted from Rosillo-Calle et al. (2008);

**crop residue coefficients or multipliers (cereals ) adopted from EL-Nouby (1991); ***crop residue coefficients or multipliers (oil seed and pulses ) adopted from Kossila (1986). Potential crop residues or by-product yield $=$ total crop yield $\mathrm{x}$ crop residue coefficient multipliers. 
Table 4: Estimates of farm animal population in a single and mixed herd owned by farm Household in the Local Government Area of Cross River State investigated

\begin{tabular}{|c|c|c|c|c|c|}
\hline Criterion & $\begin{array}{l}\text { Total No. of } \\
\text { respondents }\end{array}$ & Farm animal & $\begin{array}{l}\text { Animal } \\
\text { population }\end{array}$ & $\begin{array}{l}\text { Average } \\
\text { animal } \\
\text { population } \\
\text { per } \\
\text { household* }\end{array}$ & $\%$ \\
\hline \multirow{7}{*}{$\begin{array}{l}\text { Single farm } \\
\text { animal } \\
\text { population }\end{array}$} & 80 & Goat & 243 & 3.04 & $\overline{44.1}$ \\
\hline & & Sheep & 127 & 1.59 & 23.0 \\
\hline & & fowl & 169 & 2.11 & 30.6 \\
\hline & & Duck & 12 & 0.15 & 2.2 \\
\hline & & pig & 0 & 0.0 & 0.0 \\
\hline & & cattle & 1 & 0.01 & 0.1 \\
\hline & & Total & 552 & 6.9 & 100 \\
\hline \multirow{7}{*}{$\begin{array}{l}\text { Mixed farm } \\
\text { animal } \\
\text { population }\end{array}$} & 96 & Goat & 881 & 9.18 & 41.6 \\
\hline & & sheep & 469 & 4.89 & 22.2 \\
\hline & & fowl & 610 & 6.35 & 28.8 \\
\hline & & Duck & 91 & 0.95 & 4.3 \\
\hline & & pig & 34 & 0.35 & 1.6 \\
\hline & & cattle & 32 & 0.33 & 1.5 \\
\hline & & Total & 2117 & 22.05 & 100 \\
\hline
\end{tabular}

*average animal population per household = Animal population / Total respondents

It is concluded that the quantity of crop byproducts generated in the State is sufficient to sustain dry season feeding of small ruminants. This will ensure unretarded growth, reproduction, milk and carcass yield which, on the other hand, are the usual occurrence during dry season when green forage is scarce.

\section{References}

Dafwang, I.I. 2006. Meat, eggs and milk from farm waste: Explorations in Animal Nutrition Research and Extension - An Inaugural lecture, University organized Lectures Committee, Vice-Chancellor's office, Ahmadu Bello University, Zaria, Nigeria (63pp).
Devendra, C. 1989. Non-conventional Feeds: Potential value for animals in the Asian on Agriculture 18(2): 58-64.

Devendra, C. and Seville, C. C. 2002. Availability and use of feed resources in crop-Animal systems in Asia. Agricultural systems 71(1):59-73

El-Nouby, H.M. 1991. The role of byproducts and crop residues in SR production In: K.O. Adeniji (ed.) Proceedings of the workshop on the improvement of small ruminants in North Africa, Cairo, Egypt 3-7 th $^{\text {th }}$ une, 1991 (pp 189).

Farrell, D.J., Jibril, H., Maldonada, P. and Manion, P.E. 2000. A note on the Comparison of feeding value of sweet potato vines and Lucerne meal for 
Boiler chickens. Animal Feed Sci. Technol. 85: 145-150.

Henning, S., Pierre, G., Tom, W., Vincent, C., Mauricio, R. and Cees, de-Hann 2006. Livestock long shadow, environmental issues options. FAO, Rome, Italy.

Idowu, O.M.O., Oduwefo, A., and Eruvbentine, D. 2005. Performance and Hypocholestrolenic response of laying hens fed cassava root sievatebased Diets. Nig. J. Anim. Prod. 32(2): 215-223.

Kossila, V. 1986. The availability of crop residues in developing countries in relation to Livestock production.

http://www.ilri.org/infoserv/webpub/fulld ocs/x5495E03. HTM.

Olorunmisomo, A.O., Osasanya, T.O. and Adewumi, M.K. 2005. Utilization of sweet potato as forage supplement to a maize stover diet by West African Dwarf Sheep. Trop. J. Anim. Sci. 8(1): $39-42$.

Oyenuga, V.A. 1978. Nigeria's foods and feedstuffs their chemistry and nutritive value. $3^{\text {rd }}$ Edition, Ibadan, University Press, University of Ibadan, Nigeria (99 pp).

Rosillo-Calle, F., deGroot, P., Hemstock, S.L., and Woods, J. 2008. NonwoodyBiomass and Secondary fuels. In: Rosillo-Calle, F., deGroot, P., Hemstock, S.L. and Woods, J. (Eds.). The Biomass Assessment Hand book, Bioenergy for sustainable environment. Earthscan Publishers,
U.K. (pp111-129).

Tuah, A.K., Orskov, E.R., and Obese, F.Y. 1994. The effect of supplementation of Cassava peel (CP) diets with graded levels of palm kernel cake (PKC) on the performance of growing Djallonke sheep. In: Lebbie, S.H.B., Rey, B. and Irungu, E.K. (Eds.). Small Ruminant Research and Development in Africa. Proceedings of the second biennial conference of the African Small Ruminant Research Network. AICC, Arusha, Tanzania 711 Dec. 1992. ILCA/CTA (pp 163167).

http://www.fao.org/wairdocs/ILRI/x5472 B/5472bow.htm

Tewe, O.O. and Kasali, O.E. 1986. Effect of cassava peel processing on performance, Nutrient utilization and physiopathology of African giant rat (Cricetomy gambianus, Water House). Trop. Agric. (Trinidad). 63(2):125128.

Williams, O.T., Fernandez-Riviera, S., and Kelly, T.G. 1997. The influence of socio-economic factors on the availability and utilization of crop residues as animal feeds. In: Renard, C. (Ed.). Crop residues in sustainable Mixed crop-livestock farming systems: Proceedings of an International Workshop, Addis Ababa, Ethiopia. ICRISTAT, ILRI, CABI (pp 25-39).

Received: $20^{\text {th }}$ Novem ber, 2010 Accepted: $18^{\text {th }}$ July, 2013 